\title{
[BD]From Weikzahood to Mediumship: How to Master the World in Contemporary Burma
}

\author{
Bénédicte Brac de la Perrière* \\ Centre Asie du Sud-Est (CNRS/EHESS)
}

\section{Abstract}

In this paper, I bring into focus the biography of a Burmese ritual specialist who combines in her practice different spiritual resources in order to master her changing world. By analysing the way in which she positions herself between different fields of practice, namely the weikza path and the spirit possession cult, I aim to show that beliefs and practices considered normatively distinct according to their relative distance from the core of Buddhism actually converge in her personal history. By bringing to light the evolution of such a specialist in terms of a "spiritual career," I seek to illuminate changes in the religious landscape that reflect those of the overall social context. Finally, this case demonstrates that magic, as a field of practice, is fully constitutive of the way the Burmese Buddhists of today think about and manage their lives, even if it has often been regarded as deviant from normative Buddhism.

\section{The Ambiguity of the Weikza Path}

When Buddhists from Burma want to act upon their world or deal with affliction, they may go to ritual specialists who are linked to spiritual figures known as weikza: these healers are the representatives of the weikza in this world. Although often labelled "wizards" in literature, ${ }^{1}$ in reality they attain their qualification through Buddhist practices, such as the strict observance of the moral precepts and intensive-concentration meditation, as well as through the mastery of specific knowledge, such as alchemy, exorcism and the arts of potent diagrams and formulae. ${ }^{2}$ These various practices are classified by the Burmese according to the main normative dichotomy prevalent in the Theravadin world, between renouncement of and involvement in this world (Pâli lokuttara/lokiya).

Actually, weikza followers combine both kinds of practices with the twofold aim of acting upon the world and of attaining spiritual perfection. Some of them are supposed to have reached such spiritual accomplishment that some Burmese think they have gone out of the rebirth cycle while remaining available in this world to rescue people. They are the weikza beings characterized by this extraordinary ontological status. Roughly speaking, they are soteriological figures emerging from the Burmese field of occult practices, and they are devoted a cult by the practitioners of this field, identified as the "weikza path" (weikza lan). The ritual specialists pertaining to the weikza path are usually initiated in cult groups linked to one or more of these spiritual beings, whose potency is crucial to their own efficiency and legitimacy.

One has to admit that the field of practice linked to the weikza does not easily fit into the normative categories prevalent in Burmese Buddhism. Not only the practices of the ritual specialists, but also the ontological status of the weikza as spiritual figures, cannot be classified as exclusively in-worldly or out-worldly. Moreover, the weikza path practitioners -religious virtuosi, yet not withdrawn from the world into the religious order 
(sangha) - do not fit into either category of the main statutory distinction prevalent in Burmese society, which posits a radical difference between monks and laity.

\section{The Weikza Path in Burma Studies on the Religious Field}

This impossibility of classifying the weikza path according to Burmese normative categories calls into question analyses made in line with emic dichotomies without asking what they are made for. The opposition common to the Theravadin world between what is in-worldly and what is out-worldly found a particularly eloquent expression, in the Burmese context, in the writings of Melford Spiro. The best known of the anthropologists of Burma, Spiro conducted his field research in villages surrounding Mandalay, at the turn of the 1960s, in the heyday of American cultural anthropology in Southeast Asian rural societies. He produced an ambitious analysis of religious phenomena in Burma, known through its critics, particularly Stanley Tambiah, as the "two religions theory" (Tambiah 1984, p. 345). While Tambiah was attempting to produce a comprehensive scheme linking together all the religious facts pertaining to a local community of Northeast Thailand (Tambiah 1970), Spiro insisted that "supernaturalism" (as he called it) and Theravada Buddhism constituted two distinctive religions. He dealt with each of them in two separate books, Burmese Supernaturalism (1967) and Buddhism and Society (1970), and responded to his critics, arguing that Burmese themselves saw both categories of facts as pertaining to two different religions. While Spiro did not include the weikza path in Burmese Supernaturalism, he categorized it as "apotropaï," compared to "nibbannic" and "kammatic" oriented practices and beliefs of Buddhism that he found in Burma, further subdividing the field of religious practices and beliefs according to their relative distance from the core of doctrinal Buddhism (Spiro 1982).

Indeed, by elaborating on this conception of the religious field in Burma, Spiro was doing nothing but reinforcing Burmese views on the matter - not just any views, but the dominant views through which Burmese hegemony is asserted (Brac de la Perrière 2009). However, other lesser known, though by no means less important, works, published during and after Spiro's time, allow us to draw a somewhat more balanced picture of the religious field in Burmese studies. For instance, Manning Nash takes a more encompassing stance on religion, stating that "the interplay of these oppositions (between this world and the other world) makes up the religious system rather than their opposition" (1966, pp. 112-3).

Among scholars, the compatibility of the weikza field of practice with the Theravadin brand of Buddhism has been repeatedly debated. The question of its affinities with the Mahayanist figure of bodhisattva has surfaced as well. Some works, particularly those of Michael Mendelson (1961), John Ferguson and Michael Mendelson (1981) and Juliane Schober (1989), have dealt specifically with the practices and beliefs linked to the Burmese figure of weikza without relegating it to the margins of mainstream Buddhism. More recently, Keiko Tosa, Patrik Pranke, Niklas Foxeus and Guillaume Rozenberg have contributed to the discussion with reflections on how to locate the weikza figure in Burmese Buddhism, still puzzled by its hybridity. ${ }^{3}$

John Ferguson and Michael Mendelson hypothesized that the weikza figure developed its soteriological dimensions during the 19th century in the context of the confrontation with modernity and colonial rule (1981, p. 74). At the time, practices linked to this figure would have coalesced into the articulation of the monastic and the lay domains as a distinctive field in the process of the rationalizing reconfiguration of the religious landscape. Whatever the case may be, the result has been that modernity has made these practices 
pertaining to magic more apparent and more in contrast with Buddhism than they used to be, rather than to cause their fading away according to Weber's theory of a disenchanted world.

Thus, the question is not only whether the weikza field of practice belongs to the Theravadin brand of Buddhism, historically and normatively; it is also one of its place in the broader context of the Burmese religious landscape. Actually, to evaluate the place of the weikza in Burmese culture and society, one needs to distinguish this field of practice from other contiguous ones. It is necessary to consider, for instance, how the practitioners of the weikza path build their position and their legitimacy against those of other ritual specialists, such as Buddhist monks or spirit mediums. This kind of approach reveals that thesestions, so well identified and generally contrasted in Burmese ideas and practices, actually emerge from the interplay between seemingly heterogeneous fields of practice. Far from being isolated, the latter must be described in their constant interactions.

\section{The Changes in the Religious Landscape}

Spiro's works on Burma have been the best known outside the close circle of specialists, and have thus contributed to a deep bias which, along with the difficulty of access to the field, has led, in the decades-since, to the ignorance of a range of facts concerning religion in Burma. Thus, practices linked to spirits by the Burmese, particularly the cult to the 37 Lords, did not benefit from much research. When I began my own enquiries into this cult in the 1980s, nothing substantial had been published on the matter since Spiro's Burmese Supernaturalism (1967). The cult in its pervasiveness and its complexity was deeply ingrained in different levels of social organization. However, at the time, it still needed systematic field research. In the process of describing it as a field of practice of its own, I discovered that this cult, devoted to the tutelary spirits by the Burmese Buddhists, was established as separate from Buddhist institutions only in order to assert hierarchical differentiation. This normative separation could not conceal that both fields of ideas and practices belonged to the same conceptual and ritual world. A close examination of the conceptual world linked to spirit worship did not demonstrate its isolation from Buddhism. On the contrary, the spirit cult dynamics best understood as responses to the evolution of the overall religious field. Indeed, 25 years of enquiries into the rituals of the spirit cult and into the circles of the spirit mediums have taught me that this field of practice, far from being merely "traditional" and forever fixed as separate from the Buddhist establishment, was in fact ever-changing and dynamic. Although perfectly identified as the cult of the 37 Lords, with its own ritual specialists (the spirit mediums, known as natkadaw, being deemed to have control over spirit possession), its boundaries were not at all static. On the contrary, they were constantly evolving according to context, both religious and societal.

In the past decade, in particular, I have gradually become aware of the progressive entry among spirits embodied by natkadaw into spirit possession séances of a different brand of entities. I would categorize them roughly as guardian spirits of pagoda entering the relatively closed circle of the tutelary spirits of the local communities belonging to the 37 Lords. Significantly, their entry into the spirit possession pantheon followed the dramatic development of their iconography in the pagodas, which was the hint of other socio-religious changes, namely those affecting the relationships between agents from the economic, political and religious spheres. The move of the spirit mediums towards figures not belonging to their recognized pantheon was linked with transformations in the overall socio- economic conditions, particularly of the urban population, 
from which the bulk of those operating in Yangon used to draw their clientele. Needless to say, the displacement of the central administration to Naypyidaw, the brand new capi$\mathrm{tal}^{4}$ following the move of large segments of the Burmese population from downtown Yangon to new satellite towns and their replacement by a newly emerging middle class of a more complex origin, ${ }^{5}$ all had a broad range of consequences on religious practices. Investigating the evolution of the practices of the spirit mediums, I came across a hybrid form of ritual, organized jointly by natkadaw and ritual specialists linked to the figure of weikza. Although not new per se, this kind of spirit possession séance was starting to involve the embodiment of figures linked to the weikza beings by the weikza followers. The natkadaw began commenting upon this new element as a break with their tradition. The natkadaw field of practice was seemingly in competition with that of the weikza in the context of these spirit possession séances, in which the interplay between the two fields of practice was ritually acted out. ${ }^{6}$ The boundaries between the different fields of practice were not only porous and delineated through such interplay, they were also changing.

\section{A Biography in the Shape of Spiritual Encounters}

I met with Ma Tin Tin U at the occasion of such a hybrid ceremony in 2007. A pretty woman in her 40s, she lives with her husband in a rather comfortable house in a quiet suburb of Yangon where service men of General Ne Win settled in the 60s. ${ }^{7}$ I came to her place-for the first time, together with the spirit medium who helped her organize a spirit possession ceremony. For my spirit medium friend, she was not an ordinary client, not being his devotee but merely needing him to set up the ritual setting for spirit possession. The ritual setting was more complex than usual: the pavilion erected in front of the house to host the possession dances to the 37 Lords, for 3 days, was actually shared by two groups of specialists, the mediums of the 37 Lords staying conspicuously in the half part beside the street, and a group of practitioners of the weikza path staying in the other half, beside the house. The difference between them was also manifested in their contrasted clothes and behaviour. Spirit mediums, mainly homosexuals men in this case, were colourfully dressed and behaved almost as lively as usual, while the weikza practitioners, mainly women, were dressed in brown, signalling their pious self-restraint. The pavilion shrines were linked by a thread to the domestic ones, upstairs, which happened to be rather elaborate, with a variety of ritual objects linked to the weikza cult. A woman was to stay there praying for the duration of the ceremony, so that spiritual manifestations would be limited to expected ones. Under the ritual pavilion, possession dances were alternately performed by mediums of the weikza path and mediums of the 37 Lords, according to a regulated time schedule. Ma Tin Tin $\mathrm{U}$, the hostess and principal donator, also played the main part, dressed as a princess to embody the Kyaikkami Lady, the guardian spirit of a pagoda located on the seaside, south of Moulmein.

When I was introduced to her husband, a retired military man, like so many of the neighbours, he immediately distanced himself from the event, stating that he was not involved in the spirit cult and that, rather than follow the weikza path, he practiced insight meditation (wipathana). The reason he had to comply with his wife's wish to celebrate this ceremony in honour of the Kyaikkami Lady, he explained, was that when the Lady was channelled through his wife, he had to admit that she was transfigured and truly become the Lady.

As for me, I noted that the weikza path followers, although higher on the spiritual scale, seemed to need spirit mediums if they wanted to propitiate their own spirits 
through possession dances. I decided to come back to interview Ma Tin Tin $\mathrm{U}$ and try to understand how she, although belonging to a weikza group, came to relate to a personal guardian who did not belong to the pantheon of traditional guardian spirits. She welcomed me and said she had been waiting for me, a common way clairvoyance ability. She received me upstairs in the bounded limits of her shrines. Apparently, she was acting as a weikza consultant for people of her surroundings to offer predictions, and, more specifically, to suggest lottery numbers and to cure disease and distress.

$\mathrm{Ma}$ Tin Tin $U$ claimed that she had been a medium of Bomingaung, currently the most popular weikza being, through whom she had received oracles since 1985. Talking about her exchanges with the weikza, she used the expression dat si- (to circulate energy), while spirit mediums would rather say nat $p u$ - (spirit is heating) or nat win- (spirit is entering) to qualify possession by the spirit. This is revealing of the fact that contact with spiritual beings is not perceived in the same way by both kinds of specialists and according to the nature of the entities involved. Ma Tin Tin U maintained, moreover, that she did not charge for her services, being content ceremonies financed by her clients, a way further differentiate herself from the spirit mediums known to extort money from their clients (although their procedure is same).

As soon as Ma Tin Tin U understood my request, she started to tell her life story in unrestrained and lavish detail, connecting all its turning points with spiritual encounters. Born in a small town in the delta, she came to Mingaladon, a satellite city to the North of Yangon, to work in a confectionary workshop, during the 1990s. ${ }^{8}$ At that time she was taken to Ma Po So, a woman follower of a weikza group known as the Nagani, or the Red Dragon. The Nagani group devotes a cult to U Kowinda, a weikza being whose dim and slightly disturbing picture has become common among the representations adorning the-domestic shrines in Yangon. It shows a skinny monk whose head is wrapped in his brown robe. As for Ma Po So, she is a medium of the weikza $\mathrm{U}$ Kowinda and of an "ogre" (bilu) who is the guardian spirit of Daddhu Kan, a pagoda situated in the outskirts of Yangon. During this first consultation, Ma Po So made the diagnosis that Ma Tin Tin U was linked with the Kyaikkami Lady, and told her that if she wanted to receive a promotion she should have a dress prepared as an offer of thanks to the Lady. Consequently, Ma Tin Tin $\mathrm{U}$ began to be involved in a cult to this Lady, to wear the dress and to be possessed by the spirit in the context of spirit possession ceremonies. Indeed, this practice is similar to that of the spirit mediums for their main spirit. However, the Kyaikkami Lady is not a tutelary spirit but the guardian spirit of the Kyaikkami pagoda. She does not belong to the spirit possession pantheon of tutelary spirits. Like other Ladies in charge of pagodas, she is rather known as thaik and related to the serpentine naga.

It was through her belonging to Ma Po So's group that Ma Tin Tin U met her husband. He had been previously in contact with Ma Po So to treat the fertility problem he had with his first wife, in the early 1990s. They ultimately had a daughter, now a teenager, thanks, they believe, their devotion to thaik Ladies: Shin Saw Bu, the Shan queen of Anawratha, who has become the prototype of thaik figures, and Ma Nwè Nan, the Lady of Bottataung pagoda, whose rising fame in the 1990s translated into the gradual increase of her shrine, eventually discarded from the pagoda platform and now standing, as a rival, on the other side of the access road to the pagoda. Later on, after his first wife died of heart disease and their daughter became ill, the husband returned to Ma Po So. She advised him to organize a spirit possession ceremony dedicated to the thaik Ladies, and asked $\mathrm{Ma}$ Tin Tin $\mathrm{U}$ to dance at the ceremony and to embody the thaik Ladies. At this occasion, they met and married in 2002, making Ma Tin Tin U, at the turn of her 
40 s, a second wife to a widowed man. From this union a son was born, who is treated as a miracle son.

From Ma Tin Tin U's story, it is difficult to say if she was already a weikza follower at the time she met Ma Po So. She did explain, however, that she had not yet "met" U Kowinda. This happened during a stay at the hospital where she was treated for an illness. Then the weikza gave her a vision of him ("he came in her mental space [mano]," as she says, according to the weikza idiom). He told her to go see his place in the hospital. She discovered a small pond where naga could have taken refuge and thought that a guardian Lady (thaik) must be dwelling there. This indicates how devotion to the weikza figure is intermingled with that of the pagoda-treasure guardian Ladies in her mind.

Ma Tin Tin U also described "encountering" the weikza U Kowinda at Popa, where Ma Po So goes every Lent to present him with offerings. Mount Popa, a volcano overlooking the Burmese central plain, was once the sacred Mountain of Pagan's kingdom and remains a famous destination for pilgrims and all sorts of spiritual practitioners. Above all, it is the place were Bomingaung, the most popular of today's weikza, "went out" of the rebirth cycle and thus attained the ambiguous state that pertains to weikza beings. Ma Tin Tin U apparently went to Mount Popa once, together with Ma Po So, having vowed to meet $U$ Kowinda. She undertook to meditate (concentration meditation, thamatha), and saw him riding a horse. She followed him despite sore feet, and climbed up "alone" to the top of the mountain along a difficult path. Then she started to meditate again and saw the guardian spirit of Popa, a beautiful Lady of fair complexion, with her two teenage sons. The three of them belong to the 37 Lords pantheon. Eventually, U Kowinda " "we but he did not let her recognize him and, fled. The elusive of her encounter with U Kowinda andirect link to this weikza. Actually, Ma Tin Tin $U$ has never really managed to get in touch with him: uncertain visions are all that she has achieved through painful efforts.

Together with Ma Po So, she has also Kyaikkami, south of Moulmein, home to the thaik Lady she is linked to. This seaside pagoda presents the partictarity a separate pavilion for women now adorned with a thaik Lady image made according to the model of the more recent statue of Mya Nan Nwè at the Bottataung pagoda. Thus, like so many pagoda-treasure guardians, both Ladies have benefited from the development of thaik iconography in the 1990s. Ma Tin Tin U went to Kyaikkami before her wedding, and her would-be husband joined the party to ask the Lady's permission to marry her. She went on her own to the women's pavilion at a time when the sea level was rising, and had to stay as flood water had separated the pavilion from the main pagoda. She undertook a standard, 45-minute meditation session, during which she saw an old man dressed in white (as some weikza are represented), and a young couple dressed as princes in the Pagan kingdom's time. The old man told her that he would allow her to "spread religion" (thathana pyu-), to propagate Buddhism, meaning that he would give her a son to ordinate as a monk, the best way for a woman to progress on the karmic path. When she left the room, she saw a man running and shouting that he could not go away. Her dream ended just when the meditation session was over.

Since their marriage in 2002, the couple had no longer been able to go to Kyaikkami, which, Ma Tin Tin U maintained, had brought on economic difficulties for their family. That is why she organized the spirit possession ceremony I attended in 2007. A client of hers promised that, if her wish to obtain a licence to import a car fulfilled, she would sponsor her pilgrimage to Kyaikkami. As Ma Tin Tin U was not yet in a position to go to Kyaikkami, she began, instead, to attend Mya Nan Nwè's anniversary in her sanctuary of Bottataung, in Yangon. She sees this thaik figure as being very close to that 
of the Kyaikkami Lady, and speaks of how, discovering the most recent statue of Mya Nan Nwè, dressed as a life-size nun, she received from the Kyaikkami Lady a request to in the same fashion. She does not know how this statue offering to the Kyaikkami Lady was made. As for Mya Nan Nwè's anniversary celebration, it has recently developed and is now performed the end of December: monastic robes and a full meal are offered to monks in the name of the Lady, and food suited for naga (milk and sweets) is sent along the river. Ma Tin Tin U's own birthday being on December 29, she has been there on this date since 2005, offering a birthday cake to any devotee showing up, on the "advice" of the Lady.

\section{The Hybridity of a Spiritual Career}

$\mathrm{Ma}$ Tin Tin $U$ turned to the weikza path as a single woman, migrating from a rural setting to the suburban world of Yangon, as a factory worker, at a time when undergoing drastic changes due to the new urban policy of the junta. Such a tale of radical displacement recalls those found in similar rapidly urbanizing societies of Southeast Asia in the 1990s (Morris 2000 and Taylor 2004). From this she managed to reach a relatively honourable status, as wife to a retired military man, mother to their son, and weikza consultant in lower-middle-class Although modest, this position has to be understood as a real achievement, which seems to have been possible thanks to her belonging to a weikza group. Incidentally, Ma Tin Tin U, so prolix about her spiritual encounters, never gave any precise account of the circumstances that led her to consult Ma Po So - whether it was her job difficulties, her illness, or even her late wedding, which prompted her initial visit, remains unknown - as if the discovery of her link to the thaik Ladies had cleanly erased her whole previous life, and her own life story had disappeared in her spiritual biography.

On her way to building her position as a specialist of a "spiritual path", her life story sounds like an argument for legitimacy. This is not to her being a follower of the weikza path; on the contrary, it is common to nearly all spiritual biographies. Her story is also, in a sense, such a standard one that it seems to cross-boundaries of differentiated fields of practice. Indeed, Ma Tin Tin U's experience is not foreign to the young, good-looking in a conventional marital life tradionally settled through their becoming the medium of one of 37 spirits Ladies, such as Ma HnèLé or Popa Lady, to whom they could turn for a womanly model.

No doubt more noteworthy is Ma Tin Tin U's position as a woman in the weikza field of practice, since the role of women in the weikza cult, particularly as practitioners, is far from self-evident. If women are present among weikza devotees, leaders of cult groups are usually men. Indeed, the spiritual accomplishment allowing the outstanding ontological status of the recognized weikza beings, along with some of the practices leading to this accomplishment (such as alchemy), seem to be barred to women. Women's ability to manifest the weikza beings' potency (dat) is open to debate: in some contexts, they are mediums of the weikza beings, while in others, this role is deemed exclusively masculine, on the grounds that such perfected beings may not be in contact with a female body.

In the weikza group led by Ma Po So, a woman devoted to the weikza U Kowinda, Ma Tin Tin $U$ acts as a medium of thaik Ladies; she does not claim to be a medium of $\mathrm{U}$ Kowinda. Far from the ascetic figures of the weikza beings associated with esoteric practices, thaik Ladies are spirits linked to pagodas, most of them young and attractive 
models of femininity. Moreover, these spirits require possession dances performed by a cult, as do the spirits belonging to the 37 Lords pantheon. Propitiating them in a ritual way entails organizing a full-fledged spirit possession ceremony, in a setting whose specialists are spirit mediums (natkadaw). Nonetheless, thaik Ladies do not belong to the pantheon of traditional tutelary spirits; they are clearly differentiated, and belong to a distinct and higher sphere of spiritual beings.

Ma Tin Tin U's discourse makes clear that it is her link to the thaik Ladies which marks her belonging to the weikza path. Significant in this regard is her insistence on describing how she connects with these beings through the systematic practice of thamatha meditation, and the fact that the words she uses to describe her experience fully pertain to the weikza field of practice. Though she may not be as accomplished in her mastery of the weikza or esoteric arts as is often expected, her practice is indisputably identified as a weikza consultancy. This could partly explain why she needs to demonstrate her link with the spiritual world through possession of lesser beings than the weikza. But her spirits, the thaik Ladies, are still higher than the possession spirits, because they are, as a rule, located in the pagoda, and are therefore directly related to the Buddhist establishment.

This also has to be related to Ma Tin Tin U's inscribing herself in her time and place. Thaik Ladies became popular in the 1990s, in the wake of urban expansion and pagoda refurbishment impelled by the junta in its attempt to reshape society and to assert its legitimacy. Private donators called upon to sponsor religious donations were rediscover imaginary figures linked to the pagoda foundation legends and ordered new images of them, which led to a complete renewal of the pagoda side iconography. At the time, when Ma Tin Tin $U$ was trying to find her way in suburban society, she took on the mood, following her master Ma Po So, and identified herself with the new images created by her generation. In this time of urban migration, it is significant that spiritual connections are redirected from local communities' traditional tutelary spirits, bounded to their domains, toward figures less community-rooted but more acceptable to Buddhist ethics.

Indeed, to identify with pagoda guardians such as thaik Ladies or "ogre" (bilu) is also to identify with figures Buddhism (thathena pyu), a highly valued role that is also shared by the weikza followers. But while the weikza role may also be assumed by women, it is general reserved men. For a woman, participating in the propagation of the religion typically means having a son in the Sangha. And, as Ma Tin Tin U explicitly the Kyaikkami Lady that she eventually married and had the son that allowed her, as a woman, to fully participate in the Buddhist community.

Finally, the spiritual biography of Ma Tin Tin U, with all its commonplaceness, bears witness to the social life and history of contemporary Burma. The spiritual resources she taps into new developments in religious beliefs and practices. That said, the articulation of such beliefs and practices, which resort to conceptually distinct spheres of religious life, may not be so new. Ultimately, Ma Tin Tin U identifies with the weikza field of practice because it offers a religious idiom socially acceptable in her lower-middle-class By doing so, she marks a distance from the spirit mediums, while still engaging with them for ritual purposes. This may be a new way of disclosing the actual dialectics that characterize the interplay between both levels of practice.

\section{Short Biography}




\section{Notes}

* Correspondence address: Benedicte Brac de la Perriere, 190 av France, 75013 Paris, France. E-mail: brac@vjf.cnrs.fr

1 See Shway Yoe, The Burman. His Life and Notions, Ch. 44, for an instance of an early description of these specialists. See also Htin Aung, "The Cult of the Magus", in Folk Elements in Burmese Buddhism (1962), for a description of the weikza followers by a Burmese scholar.

2 About the importance of alchemy in practices linked to the weikza, see Guillaume Rozenberg (Les Immortels, 2010), and about potent diagrams and formulae, see Thomas Patton, in Brac de la Perrière and Rozenberg 16 (forthcoming).

3 A panel was convened by Guillaume Rozenberg and myself on this very topic at the conference of Burma Studies held in Marseille in July 2010. Papers from this panel have been collected in Brac de la Perrière and Rozenberg (forthcoming).

4 The seat of administration and government was moved from Yangon to Naypyitaw, some $500 \mathrm{~km}$ towards the north, in November 2004, almost suddenly, a dramatic move reminiscent of those of the royal cities when a new king ascended to the throne.

5 When the new junta came to power after the events-of 1988, it started an ambitious urban policy huge satellite towns in the outskirts of the old cities, first of all in the periphery of Yangon, to relocate people living in crowded downtown areas.

6 I have identified these processes in the three forthcoming papers referred to in the bibliography.

7 The Gat Ne Win came to power in 1962 and led the junta as head of state until the revolt movement of 1988.

8 The opening of market economy under the SLORC rule, at the beginning of the 1990s, attracted investors and created job opportunities in the suburbs, particularly in the garment industry. This came to an end due to the combined difficulties of the financial crisis (1997) and of the policy of sanctions against the junta.

\section{Works Cited}

Aung, Htin. (1962). Folk Elements in Burmese Buddhism. 2??: London University Press.

Brac de la Perrière, Bénédicte. (2009). An Overview of the Field of Religion in Burmese Studies, Asian Ethnology, 68-2, pp. 185-210.

—. (forthcoming a). Being a Spirit Medium in Contemporary Burma. In: Kirsten Endres and Andrea Lauser (eds.), Engaging the Spirit World in Modern Southeast Asia, pp. ??? ??? ???: Berghahn Books.

- (forthcoming b). Mediating Spirits and Mediating Weikza: Two Competing Fields of Practices. In: Bénédicte Brac de la Perrière and Guillaume Rozenberg (eds.), What Kind of Buddhism is that? A Collective Inquiry into the Burmese Weikza Phenomenon, pp. ??? ??? ???: ???.

. (forthcoming c). Possession and Rebirth in Burma (Myanmar). Special issue. In: N. Tannenbaum (ed.), Contemporary Buddhism, pp. ??? ??? ???: ???

Ferguson, John P. \& Mendelson, E. Michael (1981). Masters of the Buddhist Occult: The Burmese Weikzas. In: ?? Ferguson (ed.), Essays on Burma. Contributions to Asian Studies, pp. 62-80. Leiden: E.J. Brill.

Foxeus, Niklas. (forthcoming). The World Emperor's Battle against the Evil Forces. In: B. Brac de la Perrière and G. Rozenberg (eds.), What Kind of Buddhism is that? A Collective Inquiry into the Weikza Phenomenon, Pp. ??? ??? 2??:???:

Mendelson, E. Michael. (1961). Messianic Buddhist Association in Upper Burma, Bulletin of the School of Oriental and Africa Studies, 24(3), pp. 560-580.

Morris, Rosalind. (2000). In the Place of Origins: Modernity and Its Mediums in Northern Thailand. Durham: Duke University Press.

Nash, Manning. (1966).

Patton, Thomas. (forthcoming). In Pursuit of the Sorcerer's Power: Sacred Diagrams as Technology of Potency. In: B. Brac de la Perrière and G. Rozenberg (eds.), What Kind of Buddhism is that? A Collective Inquiry into the Weikza Phenomenon, pp. ??? ??? ???:???

Pranke, Patrick. (1995). On Becoming a Buddhist Wizard. In: D. S. Lopez (ed.), Buddhism in Practice, pp. $22 ?$ ?2? 222: Princeton University Press.

Rozenberg, Guillaume. (2010). Les Immortels.

Schober, Juliane. (1989). Paths to Enlightment. Theravada Buddhism in Upper Burma. Unpublished PhD thesis, Urbana-Champaign: University of Illinois.

Spiro, Melford E. (1967). Burmese Supernaturalism. A Study in the Explanation and Reduction of Suffering. New Jersey: Prentice Hall Inc. 
(1982). Buddhism and Society. A Great Tradition and Its Burmese Vicissitudes. Berkeley: University of California Press (1970).

Tambiah, Stanley J. (1970). Buddhism and Spirit Cults in North-East Thailand.???: Cambridge University Press. . (1984). The Buddhist Saints of the Forest and the Cult of Amulets. 22?: Cambridge University Press.

Taylor, Philipp. (2004). Goddess on the Rise: Pilgrimage and Popular Religion in Vietnam. Honolulu: University of Hawai'i Press.

Tosa, Keiko. (forthcoming). From Bricks to Pagodas: Weikza and the Rituals of Pagoda Building. In: B. Brac de la Perrière and G. Rozenberg (eds.), What Kind of Buddhism is that? A Collective Inquiry into the Weikza Pp.

Yoe, Shway. (1963). The Burman, His Life and Notions. New York: The Norton Library (1896). 


\section{Author Query Form}

Journal: $\quad$ REC3

Article: $\quad 329$

Dear Author,

During the copy-editing of your paper, the following queries arose. Please respond to these by marking up your proofs with the necessary changes/additions. Please write your answers on the query sheet if there is insufficient space on the page proofs. Please write clearly and follow the conventions shown on the attached corrections sheet. If returning the proof by fax do not write too close to the paper's edge. Please remember that illegible mark-ups may delay publication.

Many thanks for your assistance.

\begin{tabular}{|c|c|c|}
\hline $\begin{array}{l}\text { Query } \\
\text { reference }\end{array}$ & Query & Remarks \\
\hline Q1 & AUTHOR: Please check the running head. & \\
\hline Q2 & $\begin{array}{l}\text { AUTHOR: please provide the short author } \\
\text { biography. }\end{array}$ & \\
\hline Q3 & $\begin{array}{l}\text { AUTHOR: Please provide the city location of } \\
\text { publisher for reference Aung (1962). }\end{array}$ & \\
\hline Q4 & $\begin{array}{l}\text { AUTHOR: Please provide the city location of } \\
\text { publisher, page range for reference Brac de la } \\
\text { Perrière (forthcoming a). }\end{array}$ & \\
\hline Q5 & $\begin{array}{l}\text { AUTHOR: Please provide the name of the } \\
\text { publisher, city location of publisher, page range for } \\
\text { reference Brac de la Perriere (forthcoming b). }\end{array}$ & \\
\hline Q6 & $\begin{array}{l}\text { AUTHOR: Please provide the name of the } \\
\text { publisher, city location of publisher, page range for } \\
\text { reference Brac de la Perrière (forthcoming c). }\end{array}$ & \\
\hline Q7 & $\begin{array}{l}\text { AUTHOR: Please provide the forenames/initials for } \\
\text { the editor Ferguson for reference Ferguson \& } \\
\text { Michael (1981). }\end{array}$ & \\
\hline Q8 & $\begin{array}{l}\text { AUTHOR: Please provide the name of the } \\
\text { publisher, city location of publisher, page range for } \\
\text { reference Foxeus (forthcoming). }\end{array}$ & \\
\hline Q9 & $\begin{array}{l}\text { AUTHOR: Please provide the document title, } \\
\text { journal title, volume number, page range for } \\
\text { reference Nash (1966). }\end{array}$ & \\
\hline
\end{tabular}




\begin{tabular}{|c|c|}
\hline Q10 & $\begin{array}{l}\text { AUTHOR: Please provide the name of the } \\
\text { publisher, city location of publisher, page range for } \\
\text { reference Patton (forthcoming). }\end{array}$ \\
\hline Q11 & $\begin{array}{l}\text { AUTHOR: Please provide the city location of } \\
\text { publisher, page range for reference Pranke (1995). }\end{array}$ \\
\hline Q12 & $\begin{array}{l}\text { AUTHOR: Please provide the name of the } \\
\text { publisher, city location of publisher for reference } \\
\text { Rozenberg (2010). }\end{array}$ \\
\hline Q13 & $\begin{array}{l}\text { AUTHOR: Please provide the city location of } \\
\text { publisher for reference Tambiah (1970). }\end{array}$ \\
\hline Q14 & $\begin{array}{l}\text { AUTHOR: Please provide the city location of } \\
\text { publisher for reference Tambiah (1984). }\end{array}$ \\
\hline Q15 & $\begin{array}{l}\text { AUTHOR: Please provide the name of the } \\
\text { publisher, city location of publisher, page range for } \\
\text { reference Tosa (forthcoming). }\end{array}$ \\
\hline Q16 & $\begin{array}{l}\text { AUTHOR: The reference citation 'Tom Patton' } \\
\text { has been changed to 'Thomas Patton' to match the } \\
\text { reference list, please check. }\end{array}$ \\
\hline Q17 & $\begin{array}{l}\text { AUTHOR: Please provide department for author } \\
\text { correspondence. }\end{array}$ \\
\hline
\end{tabular}


Required software to e-Annotate PDFs: Adobe Acrobat Professional or Adobe Reader (version 8.0 or above). (Note that this document uses screenshots from Adobe Reader $\mathbf{X}$ )

The latest version of Acrobat Reader can be downloaded for free at: http://get.adobe.com/reader/

Once you have Acrobat Reader open on your computer, click on the Comment tab at the right of the toolbar:

닙

This will open up a panel down the right side of the document. The majority of tools you will use for annotating your proof will be in the Annotations section, pictured opposite. We've picked out some of these tools below:

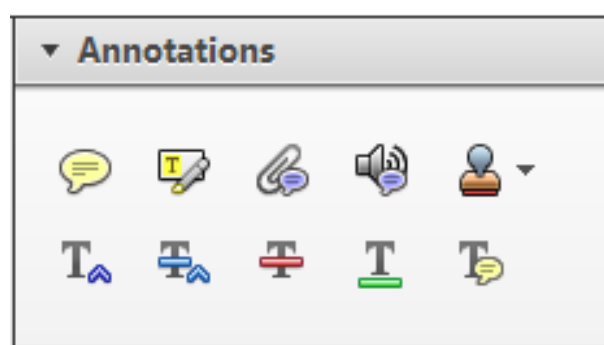

1. Replace (Ins) Tool - for replacing text.

Strikes a line through text and opens up a text box where replacement text can be entered.

\section{How to use it}

- Highlight a word or sentence.

- Click on the Replace (Ins) icon in the Annotations section.

- Type the replacement text into the blue box that appears.

Idard tramework for the analysis of $\mathrm{m}$ icy-Nevertheless, it also led to exog،

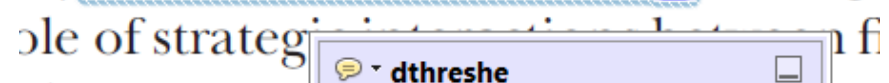
aber of comp 08/06/2011 15:58:17 is that the $\mathrm{s} 1$, which led of nain compo: be level, are exc nc

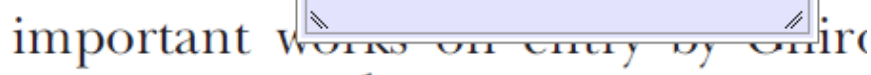
M heneforth) ${ }^{1}$ we anen the "hlarl $\mathrm{h}$

3. Add note to text Tool - for highlighting a section to be changed to bold or italic.

Th Highlights text in yellow and opens up a text box where comments can be entered.

\section{How to use it}

- Highlight the relevant section of text.

- Click on the Add note to text icon in the Annotations section.

- Type instruction on what should be changed regarding the text into the yellow box that annears.

namic responses of mark ups ent with the VAR evidence

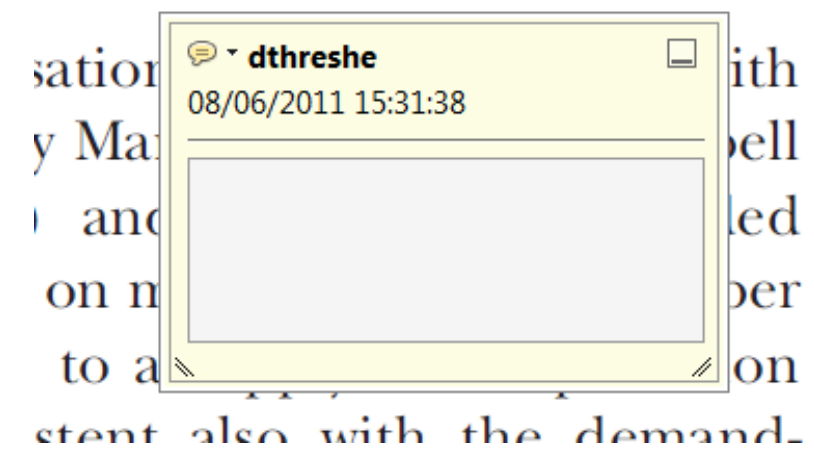

2. Strikethrough (Del) Tool - for deleting text.

Thikes a red line through text that is to be deleted.

\section{How to use it}

- Highlight a word or sentence.

- Click on the Strikethrough (Del) icon in the Annotations section.

there is no room tor extra prohts al c ups are zero and the number of ret) values are not determined by Blanchard and Kiyotaki (1987), rfect competition in general equilil ts of aggregate demand and supply lassical framework assuming monol eon an evorenois number of firms

4. Add sticky note Tool - for making notes at specific points in the text.

Marks a point in the proof where a comment needs to be highlighted.

\section{How to use it}

- Click on the Add sticky note icon in the Annotations section.

- Click at the point in the proof where the comment should be inserted.

- Type the comment into the yellow box that appears.

lallu allu suppiy silucks. Iviusl ul

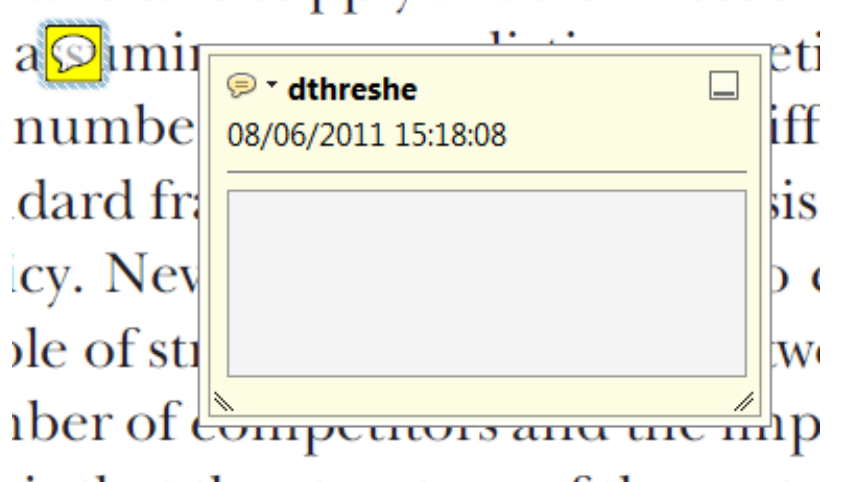

is that the structure of the secto 
5. Attach File Tool - for inserting large amounts of text or replacement figures.

Inserts an icon linking to the attached file in the appropriate pace in the text.

How to use it

- Click on the Attach File icon in the Annotations section.

- Click on the proof to where you'd like the attached file to be linked.

- Select the file to be attached from your computer or network.

- Select the colour and type of icon that will appear in the proof. Click OK.

E N D

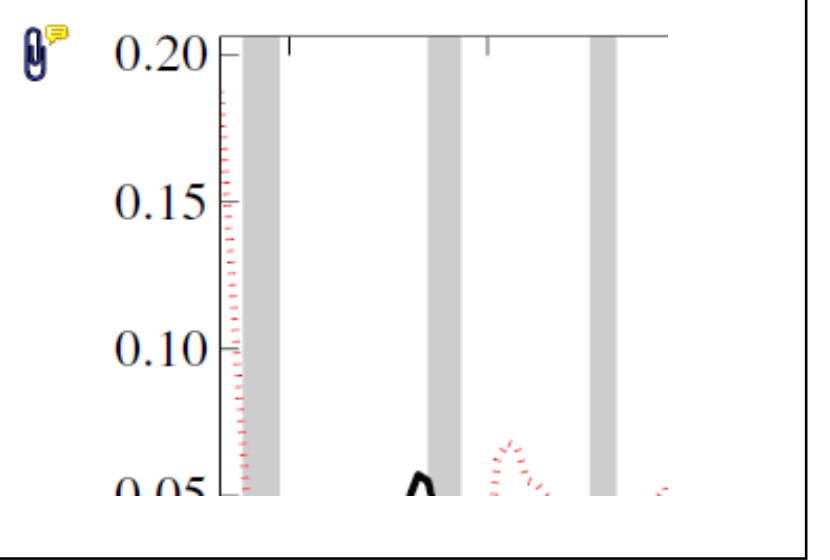

6. Add stamp Tool - for approving a proof if no corrections are required.

- Inserts a selected stamp onto an appropriate place in the proof

\section{How to use it}

- $\quad$ Click on the Add stamp icon in the Annotations section.

- $\quad$ Select the stamp you want to use. (The Approved stamp is usually available directly in the menu that appears).

- Click on the proof where you'd like the stamp to appear. (Where a proof is to be approved as it is, this would normally be on the first page).

of the Dusiness cycie, starting with the on perfect competition, constant ret

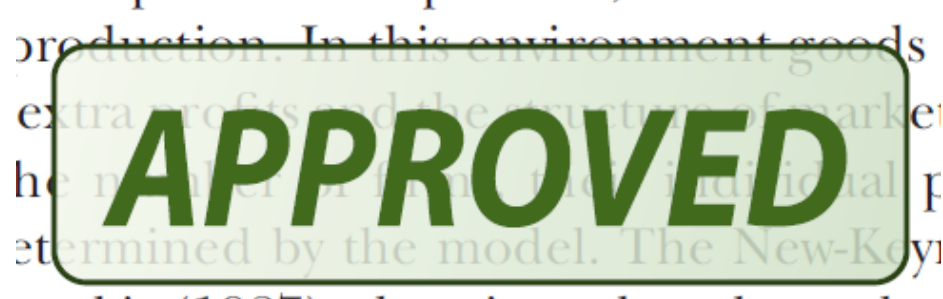

otaki (1987), has introduced produc general equilibrium models with nomin
- Drawing Markups

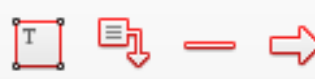

$0 \square \sqrt{6} D$

\section{How to use it}

- Click on one of the shapes in the Drawing Markups section.

- Click on the proof at the relevant point and draw the selected shape with the cursor.

- To add a comment to the drawn shape, move the cursor over the shape until an arrowhead appears.

- Double click on the shape and type any text in the red box that appears.
7. Drawing Markups Tools - for drawing shapes, lines and freeform annotations on proofs and commenting on these marks.

Allows shapes, lines and freeform annotations to be drawn on proofs and for comment to be made on these marks..

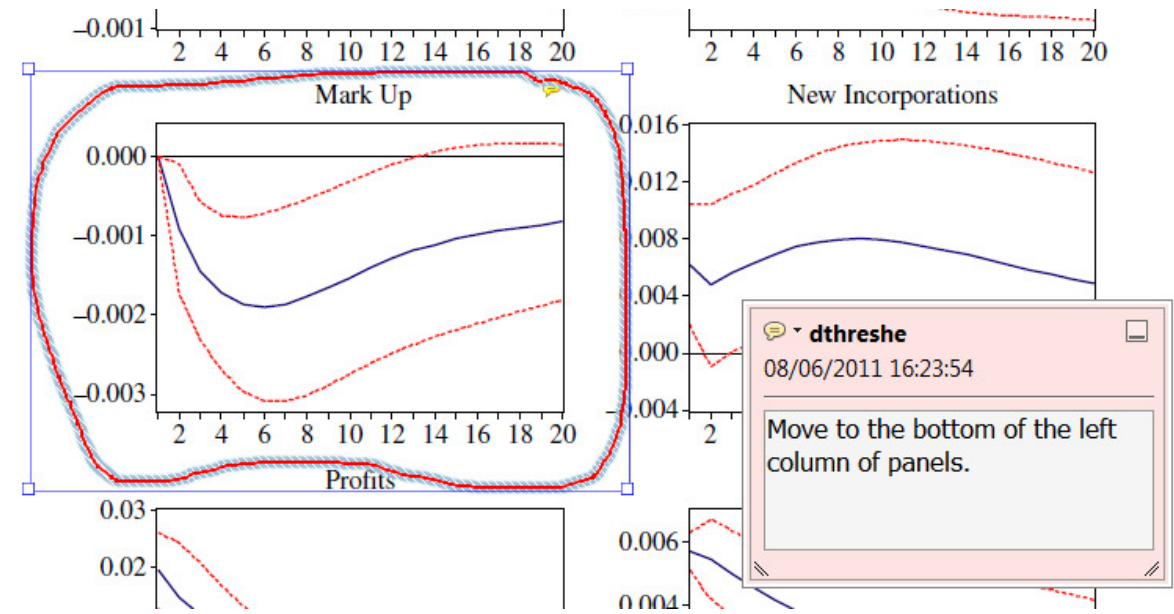

For further information on how to annotate proofs, click on the Help menu to reveal a list of further options:

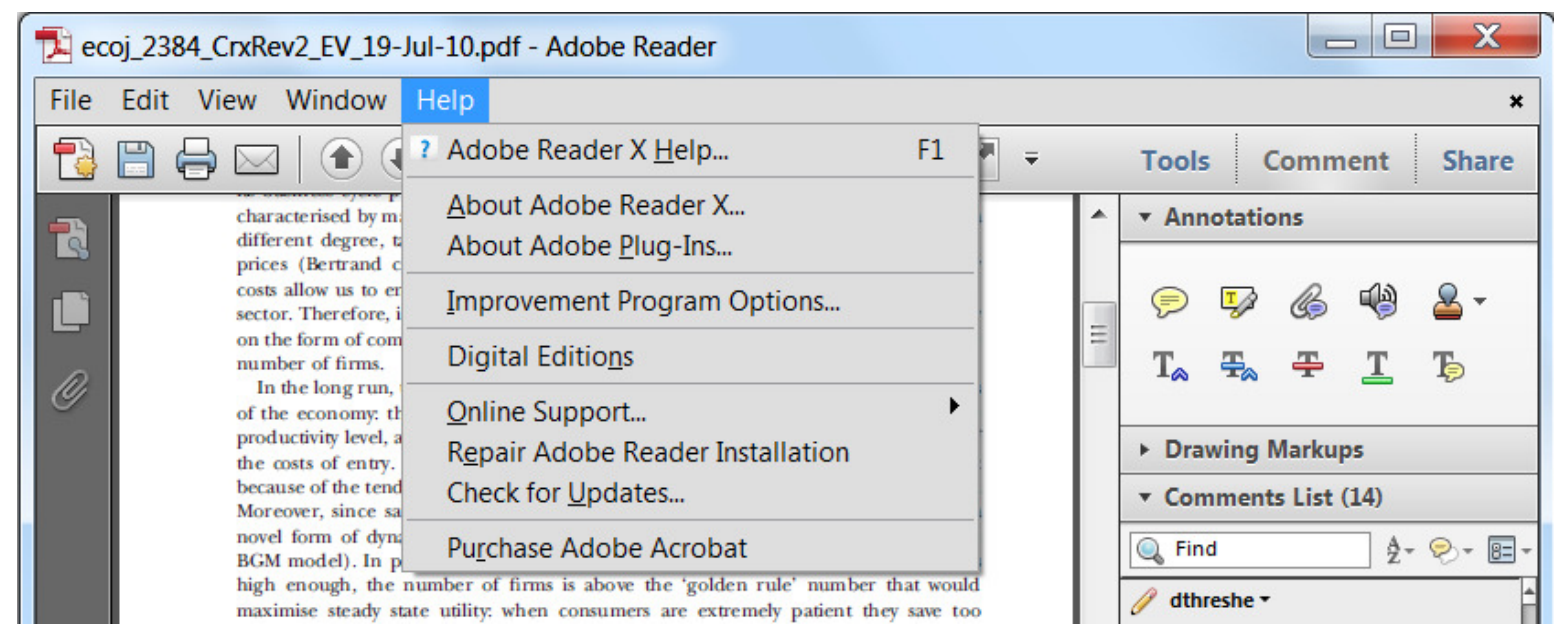

